\title{
The analysis of child marriage and third- party consent in the case of Rebeca $Z$. Gyumi v Attorney General Miscellaneous Civil Case no 5 of 2016 Tanzania High Court at Dar es Salaam
}

\author{
Norah Hashim Msuya \\ LLB LLM PhD \\ Postdoctoral Researcher, School of law, University of KwaZulu Natal
}

\begin{abstract}
SUMMARY
The Tanzanian High court handed down the remarkable judgment in Rebeca Z. Gyumi v Attorney General Miscellaneous Civil Case No 5 of 2016 HC Dar es Salaam on July 8, 2016. The court considered whether sections 13 and 17 of the Act violate the right to equality, the right to expression and receipt of information as provided for under Articles 12, 13, 18 and 21 of the Constitution of the United Republic of Tanzania 1977 (hereinafter referred to as the Constitution). The court therefore ordered the government to review the law in accordance with its obligations under international human rights law, with a view to setting the age of marriage at 18 , with the full consent of the girl, and without exceptions. However, the Tanzanian government filed an appeal against this High court judgment on September 2017. In the light of the foregoing, this study analyses the above judicial decision, highlights the areas where the ruling makes a significant jurisprudential contribution and examine the impact of third-party consent to child marriage and early marriage on human dignity.
\end{abstract}

\section{Background}

On July 8, 2016, the Tanzanian High Court delivered a judgment concerning sections 13 and 17 of the Tanzania Marriage Act CAP R.E. 2002 (hereinafter referred to as the Act), which provides a different age for the marriage of girls and boys. The Act permits a girl child under the age of 18 to marry with the consent of a third party such as a parent or guardian. Section 13(1) of the Act specifically deals with the minimum age of marriage and sets the minimum age at 18 for boys and 15 for girls with parental consent to marry. ${ }^{1}$ It also permits girls to marry at the age of 14 with the court's permission. While, section 17 of the Act permits girls from 15 years to get married with the consent of their parent or guardian. ${ }^{2}$

S13 (1) of the of the Tanzania Marriage Act CAP R.E. 2002.

S 17 of the of the Tanzania Marriage Act CAP R.E. 2002.

How to cite: Msuya 'The analysis of child marriage and third-party consent to child marriage in the case of 
This precedent-setting case was petitioned by Rebeca Gyumi, who is the director and founder of the msichana initiative, a non-governmental organisation that advocates for the rights of women and young girls. The petitioner sought two orders from the court, one that the court declare the provisions of sections 13 and 17 of the Act null and void, as far as they relate to the girl child. Furthermore, to expunge them from the statute and thereafter declare 18 as the age of competence, making both girls and boys eligible to enter into marriage without any exceptions. Two, the petitioner prayed to the court to consider 18 to be the minimum age of marriage for both boys and girls until the government amends the law.

The respondent was the Attorney General, acting on behalf of the government of Tanzania, who, upon being served with the petition, filed a reply and maintained that the provisions of sections 13 and 17 of the Act do not infringe a child's fundamental rights.

Acknowledging that the relief sought constituted a reasonable and effective means of enforcing the fundamental rights of the girl child subjected to early marriage, the court called for the hearing of the petition on 3 March 2016. The petition was heard by way of written submissions and the case was presided over by three judges, namely Shabani Ally Lila J., Sekieti Suleiman Said Kiiyo J. and Ama-Isario Ataulwa Munisi J. This article aims to show that above everything else this affirmative judgment contributed to the legal certainty of women and children's rights, and specifically of the protection from discriminating and harmful traditional practices. More specifically, it goes a long way to clarifying the effect of sections 13 and 17 of the Act on human dignity, and the importance of Tanzania honouring its international obligations.

\section{Petitioner's submission to the Court}

The petitioner, through her counsel, Mr Jebra Kambole, filed an application under the provisions of articles 26(1)(2) and 30(3) of the Constitution, ${ }^{4}$ sections 4 and 5 of the Basic Rights and Duties Enforcement Act, Cap 3 R.E. 2002 and Rule 4 of the Basic Rights and Duties Enforcement (Practice and Procedure) Rules 2014. ${ }^{5}$ Article 26(1) of the Constitution states that all people have a duty to observe and abide by the Constitution and the laws of the land, while article 26(2) guarantees every person the right to take legal action to protect the Constitution and the laws of the land. Article 30(3) of the Constitution gives room for any person to seek redress in the High Courts for the

3 Para 9.

4 Art 26(1) (2) and 30(3) of the Constitution of United Republic of Tanzania, 1977.

5 Basic Rights and Duties Enforcement (Practice and Procedure) Rules, 2014 Made under S 15 The Basic Rights and Duties Enforcement Act Cap 3 R.E. 2002. 
infringement of basic rights, freedoms and duties guaranteed by the Constitution. ${ }^{6}$

Sections 4 and 5 of the Basic Rights and Duties Enforcement Act and Rule 4 of the Basic Rights and Duties Enforcement (Practice and Procedure) Rules 2014, provide for the procedure for redressing basic rights and duties guaranteed under provisions 12 to 29 of the Constitution. $^{7}$ The petitioner through the above laws challenged the constitutionality of the provisions of sections 13 and 17 of the Law of Marriage Act. The petitioner raised four issues, which were all adopted by the court as discussed below.

\section{Unconstitutionality of sections 13 and 17 of Marriage Act}

The first issue raised by counsel of the petitioner was that the provisions of sections 13 and 17 of the Act contravene the right to equality as provided for under articles 12,13 and 18 of the Constitution. ${ }^{8}$ Article 18 of the Constitution provides for the right to freedom of expression, while article 12 of the Constitution guarantees the right to equality for all human beings and article 13 guarantees equality before the law, specifically sub-articles (1) and (2) which stipulate that:

(1) All persons are equal before the law and are entitled, without any discrimination, to protection and equality before the law.

(2) No law enacted by any authority in the United Republic shall make any provision that is discriminatory either of itself or in its effect. ${ }^{9}$

The petitioner strongly contended that the provisions, at issue in the Act, infringe the right to equality because they allow a girl aged 15 to enter into marriage at an age when she cannot make decisions for herself. His argument relied on the definition of the child adopted by various Tanzanian domestic laws, such as section 4 of the Law of the Child Act, 21 of 2010 , section 4 of the Employment and Labour Relations Act, No 6 of 2004, and even the Law of Marriage Act itself. The cited laws defined a child as a person under the age of $18 .^{10}$ In this regard, the petitioner asked how the Act could retain provisions that allow a person, which it had already defined as a child to enter into marriage.

It was further argued that children are vulnerable and thus deserve protection from enormous commitments and undertakings reserved for adults due to their age. Counsel added that apart from serious matrimonial obligations and responsibilities, child marriages attract complex health hazards, which are incompatible with the best interests

6 Art 30 (3) of the Constitution of United Republic of Tanzania, 1977

7 Art12 to 29 of the Constitution of United Republic of Tanzania, 1977.

8 Para $1(\mathrm{a})$.

9 Art 13(1) and (2) of the Constitution of United Republic of Tanzania, 1977.

10 Para 9. 
of a girl child. ${ }^{11}$ He added that, since various laws confirm that a person under the age of 18 is a child, it is logical to conclude that such a person does not have the capacity or competence to enter into a lawful marriage contract, which ironically has turned out to be the justification for consent as a requirement. ${ }^{12}$ He went on to say that the provisions of section 13(2) of The Law of Marriage Act, ${ }^{13}$ which require leave from the court for the marriage of a person aged 14, can be "arbitrarily interpreted" and deny children the right to education, which is a "cornerstone of the freedom of expression" guaranteed in the Constitution. ${ }^{14}$

\section{Discrimination on the minimum legal age of marriage for boys and girls under section 13(1) of the Marriage Act}

The second issue raised by the petitioner is that the provisions of section 13(1) of the Act, which allow a female to get married at the age of 14 and a male to get married at the age of 18 and above are discriminatory. Resulting in infringing the right to equality as protected by articles 12 and 13 of the Constitution. ${ }^{15}$ The petitioner criticised the two provisions, arguing that they are discriminatory as they differentiate between boys and girls with regard to the eligible age for marriage. ${ }^{16}$ It was further argued that the law that treats people differently under similar circumstances is discriminatory. ${ }^{17}$

The petitioner invited the court to look at international and regional instruments that support the fight against discrimination, which he insisted are in accordance with the constitutional intention to preserve and uphold human dignity intended to eliminate discrimination, which Tanzania has signed and ratified. ${ }^{18}$ To that end, the petitioner cited among others the Universal Declaration of Human Rights of 1945 (UDHR), article 26 of the International Covenant on Civil and Political Rights of 1966 (ICCPR), article 2 of the Convention on the Elimination of All Forms of Discrimination against women of 1979 (CEDAW), articles (1) and (2) of the Convention on the Rights of the Child of 1986 (CRC), article 3 of The African Charter on the Rights and Welfare of the Child of 2001 (ACRWC), article (2) of the Protocol to the African Charter on Human and Peoples' Rights on the Rights of Women of 2003 (Maputo Protocol). ${ }^{19}$ The provisions in the above-cited instruments require member states to adopt legislation that advocates for equality and total elimination of all forms of discrimination.

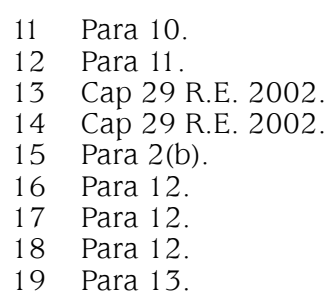




\section{A 15-year-old girl child can be married with the consent of the parent, guardian or court under section 17 of the Act}

On the third issue, the petitioner criticised the provisions of section 17 , which allow a child aged 15 to marry with the consent of the parent, guardian or court if the parent's consent is withheld unreasonably or that it is impracticable to obtain. Counsel for the petitioner submitted that, despite the explicit requirement of the parent or guardian's consent provided for under the above-mentioned section. Before a girl child can enter into marriage, the same provision waives this requirement when the parent or guardian is unavailable, which implies that this child's marriage infringes the law. ${ }^{20}$ Therefore, he argued that these provisions are unconstitutional as they infringe Article 12 of the Constitution that guarantees the right to equality and the dignity of human beings. ${ }^{21}$

He further contended that such infringement constitutes a serious abrogation because the girl child is not free to choose her life partner without seeking the consent of the parent or guardian. ${ }^{22}$ In this respect, counsel argued, it would have made more sense if the law did not allow a girl child to get married until she attain the majority age of 18 when she would be legally able to make her own decisions, similar to her male counterpart. ${ }^{23}$ He emphasised that all human beings are equal and that someone cannot decide on behalf of another, thereby contravening the above-mentioned constitutional right to equality and dignity of a person, and the right not to be discriminated against. Furthermore, it was submitted that there is discrimination between girls with parents/ guardian and those without parents/guardian, in that those with parents/ guardian will get consent, while those without parents/guardian are treated differently. The petitioner proposed that the best remedy for this anomaly is to do away with the requirement for consent and declare the eligible age for marriage to be 18 , which is in line with the right to freedom enshrined in article 21(2) of the Constitution, which stipulates that:

"Every citizen has the right and the freedom to participate fully in the process leading to the decision on matters affecting him, his well-being or the nation." 24

20 Para 9.

21 Para 9.

22 Para 10.

23 Para 10.

24 Art 21(2) of the Constitution of the Constitution of United Republic of Tanzania, 1977. 


\section{14-year-old child marriage through leave of the court under section 13(2) of the Marriage Act.}

With regard to the last issues, the petitioner submitted that the provisions of section 13(2) of the Act, which requires leave of the court for the marriage of a person aged 14 , is too vague. This because it can be arbitrarily interpreted to mean that children are denied the right to education, which is a cornerstone of freedom of expression as provided for by article 18 of the Constitution. Furthermore, the petitioner's counsel invited the court to be persuaded by the decision of the Constitutional Court of Zimbabwe, which deliberated on a similar matter in the case of Loveness Mudzuru \& Ruvimbo Tsopoddz v Minister of Justice Legal \& Parliamentary Affairs and Others, Constitutional Application No. 79 of 2014 (unreported). ${ }^{25}$ In this case, the court declared unconstitutional the provisions of the Zimbabwe Marriage Act, which are mutatis mutandis with sections 13 and 17 of the Act. ${ }^{26}$

The petitioner invited the court to adopt a liberal interpretation of the impugned sections to give the intended effect and ensure the enjoyment of the guaranteed rights provided therein. The petitioner's counsel advised the court that the interpretation should mainly consider whether a right not to be discriminated against and the right to education and equality before the law are realised by the application of sections 13 and 17 of the Act. ${ }^{27}$ To support the argument, counsel cited the case of Kukutian Ole Pumbun and Another v Attorney General and Another (1993) TLR 159, DPP v Daudi Pete (1993) TLR 22, and Julius Ishengoma Francis Ndyanabo V Attorney General, Civil case No 64 of 2001, or [2001] 2EA 485 (CAT) ${ }^{28}$ The petitioner maintained further that the constitutional rights of young girls continued to be infringed by the submission of evidence in newspapers issued on the same day as his submissions in court, ${ }^{29}$ which reported the arrest of a 70-year-old man who married a 14-year-old girl. ${ }^{30}$ In that context the petitioner unequivocally submitted that the pinpointed discrimination imposes more harm on girls than boys and therefore does not meet the proportionality test, which was applied in the case of Kukutia ole Pumbun and Another $v$ Attorney General and Another (1993) TLR 159 by the Court of Appeal. ${ }^{31}$

\section{Respondent's submission to the court}

The respondent, who is the Attorney General acting on behalf of the government of Tanzania in arguing the case strongly, resisted the claim

\footnotetext{
25 Para 14.

26 Para 23.

27 Law of Marriage Act CAP R.E. 2002.

28 Para 23.

29 Mwananchi Newspaper (2016-03-20) 3.

30 Para 24.

31 Para 24.
} 
that the provisions infringe children's fundamental rights. ${ }^{32}$ The Attorney General, represented by the Senior Principal State Attorney, responded to the petitioner's four issues cumulatively, as shown below.

\section{Advancing the argument on the unconstitutionality of sections 13 and 17 of the Act}

Council for the respondent began her submission by expounding the importance of the provisions of the Act. She contended that the provisions of the Law of Marriage Act in 1971 were the Government's response to sentiments aired by the public through the White Paper No. 1 of $1969 .{ }^{33}$ Therefore, the provisions of the Act reflected the will of the people at that time. She added that the Act was a compromise to address and accommodate the differences existing in traditional, customary and religious values of divergent communities pertaining to marriage and related issues. Counsel submitted that the minimum age of marriage was among the issues causing protracted debate by the passing of the Act. In that regard, she emphasised that the Act has a firm foundation. ${ }^{34}$ Responding to whether the provisions of sections 13 and 17 of the Act contravene the provisions of articles 12(4)(5) and 18 of the Constitution, the respondent contended that it is apparent from the stated religious and cultural beliefs that the issue being challenged is a delicate one, and not an easy fix. ${ }^{35}$ The respondent referred to section 11 of the Judicature and Application of Laws, Act, Cap 358 R.E. 2002, and the Local Customary Law (Declaration) Order, GN 279 which provide for the application of customary law, which she thought was irrelevant in determining the constitutionality of sections 13 and 17 . She argued that these provisions allow each ethnic group to make decisions based on its customary norms, traditions and religious values. ${ }^{36}$

\section{Advancing the argument on the discriminatory nature of sections 13 and 17 of the Act}

Addressing the contention that the provisions of sections 13 and 17 of the Act are unconstitutional on grounds of discrimination, the respondent ironically resisted the contention, based on section 13(2) \& (3) of the Act, which referred to the requirement of the court's leave before a girl could conclude a marriage. The respondent insisted that this requirement is sufficient protection. 37 She went on to argue that, in any event, since subsection (3) refers to "persons" and not only the girl child, there is no discrimination, because boys could also seek the court's leave if they wish to marry at an age below 18 as long as they are older than 
14 , and there are special circumstances necessitating the contracting of the intended marriage. ${ }^{38}$

The respondent considered baseless the petitioner's apprehension that the uncontrolled discretion conferred by section 13(2) in granting leave may be interpreted arbitrarily. In this context, the respondent argued that statutes define the court's powers, and therefore it is unjustifiable to presume that the court will abuse its power without any facts to substantiate the allegation. ${ }^{39}$ The respondent added that courts have been designated to be the final authority for dispensing justice by article 107A(1) of the Constitution and they are to act with impartiality. In this regard, the respondent submitted that there is every reason to believe that courts administered by competent professionals will consider the principle of the "best interests of the child" while adjudicating on all matters pertaining to children. However, the respondent condemned this argument saying that if this point is taken at face value, it will label the judiciary as an incompetent institution that does not understand its mandate, which cannot be justified. ${ }^{40}$ With regard to article 13(5) of the Constitution, she concluded that age is not one of the considerations for gauging discrimination, and so the petitioner's argument that article 13 has been infringed has no merit. ${ }^{41}$

The respondent criticised the way in which the petitioner interpreted the contested provisions of the Act. She maintained that the two provisions should be read together with the rest of the provisions to get the intended meaning. Her argument relied on the principle set out in the case of Christopher Mtikila v The Attorney General, Misc. Civil Case No. 10 of 2005 (unreported) where the court of appeal explained how to interpret statutes. ${ }^{42}$ She submitted that, to appreciate the import and context of the provisions of section 17 , they should be read together with the preceding sections of the Act. The respondent also alerted the court to the danger of removing provisions of the law or some of them without adequate justification while the government is making an effort to remedy these incongruities. ${ }^{43}$

\section{Advancing the argument on section 13(2) of the Act on denying girls under 18 the right to education}

Again, the respondent considered ill-founded the petitioner's argument that the provision of the Act denies girls the right to education, hence infringing the right to freedom of expression guaranteed in article 18 of the Constitution. ${ }^{44}$ The respondent considered this argument "too vague 
and susceptible to being interpreted arbitrarily". 45 It was the respondent's submission that parents have a duty to ensure that their children from 7 years old are enrolled to attend and finish primary school, which is compulsory. In this context, she maintained that it is not expected of a parent to give consent to the marriage of a child before he or she finishes his or her compulsory primary education, which by that time they might then have attained the majority age and be capable of making their own decisions. ${ }^{46}$

On top of that, the respondent opposed the petitioner's claim that the right of a girl child to receive information and the right to freedom of expression are infringed by the failure to be educated. She contended that the allegation is very serious if there is no evidence to support it. She added that it is not essential for a person to attend a conventional school to be able to enjoy the right to receiving information or the right to freedom of expression. The respondent contended that, in any event, some boys and girls in societies have chosen not to attend school and yet are enjoying their right to freedom of expression and receiving information without any limitations, and so she repudiated the allegation.

\section{Advancing the argument on the relevant regional and international instruments cited}

In advancing the argument on the application of regional and international instruments cited by the petitioner, the respondent agreed that some of these instruments, with a few exceptions, advocate for the position of the petitioner. In that regard, the respondent cited the South African Development Community (SADC) Protocol on Gender and Development of 2008 as an example, which provides that marriage laws should ensure that no persons under 18 should marry unless otherwise specified by law, which takes into account the interests and welfare of the child involved. ${ }^{47}$

In contradiction to what was advanced above, the respondent without availing any material evidence, notified the court that the Law of Marriage Act has been debated lately and the government has already instructed the Law Reform Commission of Tanzania to revisit the disputed provisions with a view of addressing apparent and future apprehensions. ${ }^{48}$ In this regard, she submitted that the stated facts confirm that government is dealing with the problem, and so she considered it a suitable way to deal with issues of a traditional and religious nature. In her prayers, the respondent not only requested the court to dismiss the entire petition with costs, but also to have regard for the efforts the government has made to remedy the situation. In this

45 Para 17.

46 Para 12.

47 Para 22.

48 Para 23. 
context, she prayed that the court give government time to conclude the work it has started of rectifying the anomalies complained about by the petitioner, and not to grant the petition. The respondent cemented her prayers by referring to article 30 (5) of the Constitution and section 13 (2) of the Basic Rights and Duties Enforcement Act Cap 3 RE 2002, which put limitations on the enforcement and preservation of basic rights and duties in the following words:

"[W]here in any proceedings it is alleged that any law enacted or any action taken by the Government or any other authority abrogates or abridges any of the basic rights, freedoms and duties set out in articles 12 to 29 of this Constitution, and the High Court is satisfied that the law or action concerned, to the extent that it conflicts with this Constitution, is void, or is inconsistent with this Constitution, then the High Court, if it deems fit, or if the circumstances or public interest so requires, instead of declaring that such law or action is void, shall have power to decide to afford the Government or other authority concerned an opportunity to rectify the defect found in the law or action concerned within such a period and in such manner as the High Court shall determine, and such law or action shall be deemed to be valid until such time the defect is rectified or the period determined by the High Court lapses." 49

\section{The High Court's judgment on the unconstitutionality of a girl child's marriage and third-party consent.}

The High Court considered whether the provisions of sections 13 and 17 of the Act contravene the rights to equality, freedom of expression and receiving information as provided for under articles $12,13,18$ and 21 of the Constitution as the main issue to be determined. Therefore, it directed itself to analyse whether the provisions of sections 13 and 17 treat girls and boys differently as far as the eligible age of marriage is concerned. The court then determined whether a girl aged under 18 is capable of being subject to complex matrimonial and conjugal obligations. It then determined whether the requirement for obtaining parents/guardian consent for a girl aged under 18 affects her undesirably. Thereafter, the court immediately disagreed with the respondent's contention that the judicial process is not appropriate for addressing the issue raised by the petitioner due to the good intentions of the impugned provisions. This led to the question as to whether there is a positive correlation between the imputed provisions of the Act and cultural and religious beliefs. The court adjudicated on these issues by considering the developments that have been taking place since 1971 when the imputed law was enacted, based on relevant international, regional and national laws.

49 S 13(2) of the Basic Rights and Duties Enforcement Act Cap 3 RE 2002. 


\section{Gender discrimination on the legal eligible age of marriage}

After its examination of discrimination on the legal eligible age of marriage between a girl and a boy and a closer reading of the provisions of sections 13 and 17 , the court agreed with the petition that it treats girls and boys differently as far as the eligible age for marriage is concerned. The provisions provide as follows:

"[S]ection 13(1) No person shall marry who, being male, has not attained the apparent age of eighteen years or, being female, has not attained the apparent age of fifteen years. (2) Notwithstanding the provisions of subsection (7), the court shall, in its discretion, have power, on application, to give leave for a marriage where the parties are, or of them is, below the ages prescribed in subsection (1) if: (a) each party has attained the age of fourteen years; and (b) the court is satisfied that there are special circumstances which make the proposed marriage desirable. (3) A person who has not attained the apparent age of eighteen years or fifteen years, as the case may be, and in respect of whom the leave of the court has not been obtained under subsection (2), shall be said to be below the minimum age of marriage. Section 17(7) A female who has not attained the apparent age of eighteen years shall be required, before marrying, to obtain the consent: (a) of her father; or (b) if her father is dead, of her mother; or (c) if both her father and mother are dead, of the person who is her guardian, but in any other case, or if all those persons are dead, shall not require consent."

The court stated that provisions of section 13(1) certainly permit girls to enter into marriage at 15 or even 14, while for boys it is between 18 and 14. The court failed to find any meaningful rationale for the requirement of a parent's or the court's consent before persons under the age of 14 could enter into marriage as provided for by section 17 . The court agreed with the petitioner that the provisions of section 13(1) blatantly give boys preferential treatment with respect to the eligible age of marriage, in that for them the eligible age is 18 while for girls it is 15 . To that end the court maintained that the provisions that treat persons in a similar situation differently are discriminatory, hence offending the principle of equality as enshrined in articles 12(1) and 13(1) and (2) of the Constitution, which guarantee the right to equality.

\section{Is a girl child under 18 capable of being subject to the matrimonial contract?}

The court went on to articulate what appears to have been a missing link in lawmakers' reasoning, which is the eligibility of a girl child to enter into marriage. In this regard, the court took notice of the definition of a child provided in numerous laws, including sections of the Marriage Act itself, the Child Act and the Labour Relations Act, which the court concurred with the petitioner that indeed the impugned provisions permit persons defined as children to enter into marriage. For this reason, the court recognised the need for the same Marriage Act to provide for the requirement of the parent's or court's consent to be obtained so that the 
desired marriage could be effected. The court pinpointed that the Marriage Act contradicts itself by explicitly stating in section 13(1) that 15 is a girl's eligible age for marriage, thereby allowing a girl child to marry at 15 , under section 17 , and requiring her before doing so to obtain the consent of her parent, guardian or the court. In that context, the court inferred that the Act itself had reservations about the capacity of a child aged under 18 to make her own decision to enter into marriage.

\section{Does parental/guardian consent for the marriage of a girl aged under 18 affect her?}

As to whether the requirement to obtain the consent of a parent or guardian for a girl aged under 18 to be married undesirably impacts a girl child, the court ruled that a girl aged under 18 is a child in all respects, and agreed that it is not desirous to subject her to complex matrimonial and conjugal obligations. The court went further to consider the serious health risks that an under 18-year-old girl is exposed to if married at such an early age. The court reached this conclusion after analysing the petitioner's reports attached to his written submission, and was persuaded by the Zimbabwean judgment in Loveless Mdzulu's case. The court agreed with the petitioner's argument that girls under 18 are not free because if they want to get married, they have to seek leave of the court and so they are not free to make their own decisions, thereby infringing their constitutional rights. The court established that certainly the right to equality is negated when there is differential treatment.

Furthermore, the court referred to article 6 of the Maputo Protocol, which encourages state parties to ensure that there is equality between men and women and they are regarded as equal partners in marriage. The article stipulates clearly under sub-article (b) that state parties should take appropriate legislative measures that guarantee free will and the full consent of both parties. Sub-section (b) of the same article provides that 18 should be the minimum age of marriage for women. Therefore the court accords with the petitioner that, having ratified this regional instrument, it is high time that Tanzania takes appropriate legislative measures to ensure that the rights guaranteed under article 21(2) of the Constitution are realised by all. Article 21(2) states that: "every citizen has the right and the freedom to participate fully in the process leading to the decision on matters affecting him, his well-being or the nation."

In addition, the court made reference to the provisions of the Sexual Offences Special Provision Act of 1998 (SOSPA) and wondered in what way after its enactment a court of law could be moved under sections $13(2)$ or $17(2)$ of the Marriage Act and grant leave for a girl under 18 to enter into marriage. SOSPA amended section 130 (2) (e) of the Penal Code and made the offence of rape as having sexual intercourse with a girl aged under 18 with or "without her consent unless the woman who is 15 or over is his wife and is not separated from the man." The High Court stressed that if the judiciary applied sections 13(2) and 17(2) and 
granted leave for a girl to be married while under 14, this would constitute the newly created offence of statutory rape.

The court emphasised that SOSPA came into force 15 years ago, and is therefore not expected to be valid for applications still being filed in a court of law seeking leave to conduct marriages. Similarly, it does not anticipate it being a criminal offence if the defence of an accused person is that the child victim is his wife. It was the court in reasoning that a male seeking leave to marry a child will be committing the offence of rape, and the parent or guardian-giving consent will be committing the offence of procuring prohibited sexual intercourse as set out by SOSPA. The court concluded that the legislative development bought in by SOPSA and the Law of the Child Act in 2010 implies that the government passively concedes to the petitioner's claims. The court's standpoint was that all legislative developments should reflect worldwide public outcry about ensuring that the welfare and protection of the girl child is enhanced and the dignity and integrity of women is safeguarded.

\section{Early marriage in relation to Tanzania's customary and religious beliefs}

The court turned to what could be seen as the crux of this case, namely the culture and religious beliefs that support girls' early marriages. In this regard, the court rightly rejected the respondent's argument that due to the good intentions of the impugned provisions, the judicial process is not appropriate for addressing the issue, because it is associated with the cultural and religious beliefs of society. The court rejected this argument for two reasons, firstly, because the Judicature and Application of Laws Act Cap 358 RE 2002, which supported her argument on this issue, prohibits the application of customary and Islamic law to the Law of Marriage Act. Section 11(4) of this Act stipulates clearly that, "notwithstanding the provisions of this Act, the rules of customary law and the rules of Islamic law shall not apply with regard to any matter provided for in the Law of Marriage Act." From the above clear wording of the law, the court unequivocally found that it is not valid to associate sections 13 and 17 of the Marriage Act with the values embedded in customary and religious law.

Secondly, the court referred to some of the international and regional instruments, which Tanzania ratified 13 years ago, particularly article 27 of the African Charter on the Welfare of the Child, of 1990, and adjudicated that customary practices affecting children adversely, cannot be considered to be good. Article 27 of that Charter requires state parties to take all appropriate measures to eliminate harmful social and cultural practices affecting the welfare, dignity, normal growth and development of the child. Having arrived at this decision, the court was also persuaded by the Zimbabwean case of Loveless Mdzulu, where the provision having an impact similar to the one in dispute was considered to have social and health impacts on children, and was declared unconstitutional. 


\section{Impact of child marriage on the right to education and freedom of expression}

The court agreed with the respondent that there are no material facts to substantiate the allegation that child marriage affects the right to education, which ultimately invades the right to freedom of expression and the right to receive information. The court found no evidence of the pleaded facts, which suggested that lack of education essentially leads to the lack of freedom of expression and an impediment to the right to receive information. However, the court took note of section 35(1) of the Education Act that provides for compulsory primary education and compels parents to make sure that their children attend school until they finish. In this regard, it declared that the level of education has no direct link with the freedom of expression or the right to receive information, and so article 18 of the Constitution has not been infringed.

The court therefore concluded that sections 13 and 17 of the Law of Marriage Act no longer serve any useful purpose and declared them invalid. Government was given one year to correct this matter and ensure that marriages take place when a girl is 18 years and gives full consent to the marriage.

\section{General Comments}

Apart from the clear instructions on the legal position regarding the minimum legal age of marriage, this judgment has contributed to the country's effort of advocating for legal reforms to ensure that existing domestic laws and policies are human rights sensitive, conforming to international human rights standards as embedded in human rights instruments ratified by Tanzania. The United Kingdom colonial authority to sustain the colonial system enacted most of the domestic legislation, which is currently in operation in Tanzania. ${ }^{50}$ This was done without careful consideration of the rights or welfare of the inhabitants and especially those of vulnerable groups such as girls. ${ }^{51}$ These laws were enacted before the principle of human rights was incorporated into Tanzania's Constitution. ${ }^{52}$ Since Tanzania's Bill of Rights became justifiable on 1st March 1988, after the expiry of the suspension period, the courts in Tanzania have positively resorted to applying human rights standards enunciated in the International Bill of Rights and other international and regional conventions, in interpreting the Bill of

50 Kabudi "The Judiciary and Human Rights in Tanzania: Domestic Application of International Human Rights Norms" 1991 Verfassung und Recht in Übersee 275.

51 Legal and Human Rights Centre (LHRC) Tanzania Human Rights Report 2013 2014 LHRC 57.

52 Msuya "Harmful cultural and traditional practices: a roadblock in the implementation of the convention on the elimination of discrimination against women and the Maputo protocol on women's rights in Tanzania" (PhD Thesis-UKZN 2017) 93. 
Rights. ${ }^{53}$ In addition to that, efforts have been made to ensure that new laws, which have been enacted since then, reflect the principle of equality. ${ }^{54}$

Further, this judgment presents a commendable example of how courts can make effective use of international law and treaties in their reasoning. The explicit reference to numerous international human rights instruments by the court in this case has provided a better basis on which to arrive at decisions. The court's use of international human rights instruments, and in particular the African Charter on the Welfare of the Child, is encouraged in the development of children's jurisprudence. ${ }^{55}$ The judgment sets an important standard for other state parties to the African Charter on the Welfare of the Child. The High Court explicit reference to numerous international instruments, accords import to treaty national obligations, which were voluntarily undertaken. However, the international instruments themselves often do not provide much aid, in interpreting the provisions of the Bill of Rights couched in similar terms. Hence, in this case the court went beyond by taking note of how similar provisions have been interpreted in foreign jurisdictions by referring to the Zimbabwean case of Mudzuru. The gist of this is that fundamental rights are not only developed at the international level, but also domestically through jurisprudence and countries' respective Bills of Rights.

The case is also very significant on the elimination of discrimination against women. While some forms of discrimination against women and girls are diminishing, gender inequality continues to hold women back and deprives them of basic rights and opportunities. ${ }^{56}$ Gender equality is essential for the achievement of human rights for all. Empowering women require addressing structural issues such as unfair social norms and attitudes as well as developing progressive legal frameworks that promote equality between women and men. ${ }^{57}$ In majority legal traditions, many laws continue to institutionalise second-class status for women and girls with regard to personal rights such as marital, parental, inheritance and property rights. These forms of discrimination against

53 Kabudi 1991 Verfassung und Recht in Übersee 274.

54 For example Art 21 and 66(1) of Tanzania's Constitution which were amended to make sure that there are special parliamentary seats for women representatives; S 7 and 33 of the Employment and Labour Relations Act No 6 of 2004.

55 Skelton "The development of a fledgling child rights jurisprudence in Eastern and Southern Africa based on international and regional instruments" 2009 African Human Rights Law Journal 482: Sloth-Nielsen \& Hove "Mudzuru \& Another $v$ The Minister of Justice, Legal and Parliamentary Affairs \& 2 Others: A review" 2015 African Human Rights Law Journal 554568.

56 Burgess "The Uneven Geography of Participation at the Global Level: Ethiopian Women Activists at the Global Periphery" 2011 Globalizations 167.

57 Meron "Enhancing the Effectiveness of the Prohibition of Discrimination Against Women" 1990 American Journal of International Law 216. 
women are incompatible with women's empowerment. ${ }^{58}$ Forcing a young girl into marriage generally means she will be separated from her family and friends and transferred to her husband like a piece of property. In an instant, she will be expected to become a woman who looks after the house and family, rather than play and study like the child she is. ${ }^{59}$ Child brides are often made to leave school, are more likely to experience domestic violence, and are at higher risk of dying from pregnancy and childbirth complications. ${ }^{60}$ Young girls who are married off are more likely to have children while still physically immature. ${ }^{61}$ They are psychologically unprepared and unequipped to become mothers, which means they tend to have more health problems during pregnancy and childbirth due to inadequate health care and their babies have a reduced chance for survival. ${ }^{62}$ It is reported that $31 \%$ of girls in Tanzania are married before their 18th birthday and 5\% are married before the age of $15 .^{63}$ According to the United Nations Children's Fund (UNICEF), Tanzania has the 11 th highest absolute number of child brides in the world. ${ }^{64}$ Tanzania is one of 20 countries, which has committed to ending child marriage by the end of 2020 under the Ministerial Commitment on comprehensive sexuality education and sexual and reproductive health services for adolescents and young people in Eastern and Southern Africa. ${ }^{65}$

58 UN Committee on the Elimination of Discrimination against Women "Impeding Tanzanian efforts to implement women's convention were male domination, physical violence, emotional abuse, women's antidiscrimination committee told" 2008 https://reliefweb.int/report/unitedrepublic-tanzania/impeding-tanzanian-efforts-implement-womens-conven tion-were-male (accessed 2019-03-22).

59 UNFPA "Marrying too young ends child marriage in Tanzania" UNFPA Child Marriage Fact Sheet (2014) http://tanzania.unfpa.org/sites/esaro/files/ resourcepdf/Child \% 20Marriagge \% 20fact \% 20sheet \% 20English \% 202014 -0.pdf. (accessed 2019-03-22).

60 ACHPR-ACERWC "Joint General Comment of the African Commission on Human and Peoples' Rights (ACHPR) and the African Committee of Experts on the Rights and Welfare of the Child (ACERWC) on ending Child Marriage" 2017 ACHPR- ACERWC 8. http://www.achpr.org/files/news/2018/01/d321/ jointgc acerwc_achpr_ending_child_marriage_eng.pdf. (accessed 2019-0422).

61 Adrathy $\mathrm{T}$ "Legal contradictions influence early marriage in Tanzania" We Write For Rights (2013-02-24). Available at https://wewriteforrights.word press.com/2013/08/24/legal-contradictions-influence-early-marriage-intanzania/ (accessed 2019-04-12).

62 General recommendation/general comment No. 31 of the UN Committee on the Elimination of Discrimination against Women and No. 18 of the Committee on the Rights of the Child on harmful practices" 2014. https:// tbinternet.ohchr.org/_layouts/treatybodyexternal/Download.aspx?symbol no $=$ CEDAW $\% 2 \mathrm{fC} \% 2 \mathrm{fGC} \% 2 \mathrm{f} 31 \% 2 \mathrm{fCRC} \% 2 \mathrm{fC} \% 2 \mathrm{fGC} \% 2 \mathrm{f} 18 \&$ Lang $=$ en . (accessed 2019-04-12).

63 Girlsnotbrides "Tanzania: What's the child marriage rate? How big of an issue is child marriage?" 2018 Girlsnotbrides https://www.girlsnotbrides.org/ child-marriage/tanzania/ (accessed 2019-04-22).

64 Unicef "Child marriage Data" 2018 Unicef 4. Available at https://data.unicef. org/topic/childprotection/ child-marriage/. (accessed 2019-04-16).

65 Unicef "Child marriage Data" 2018. Unicef. https://data.unicef.org/topic/ child-protection/child-marriage/ (accessed 2019-04-12). 
Although the court has set a milestone in adjudicating on the recognition of women's rights in this case, it did not address the aspect of infringement of human dignity raised by the petitioner, which is central to the practice of child marriage and attitudes towards the sexuality of young girls. These customs and religious practices that support girls' early marriage degrade human dignity. For instance, child marriages are associated with the payment of dowries, which largely violate the dignity of the girl child by treating her as the means of securing some material or non-material assets. Her body and sexuality are regarded as property that families can exchange for economic gain or honour or both. The desire to maintain a girl's virginity before marriage is a powerful motivation for getting her married early, which denies her the right to receive comprehensive information and education on her sexuality, and restricting her freedom to make decisions regarding sexual relationships. ${ }^{66}$ The practice of child marriage therefore sustains the violation of a host of other human rights of the girl child, such as the right to sexual and reproductive health, information and education on sexuality. ${ }^{67}$ It is highly significant that human dignity appears before both equality and freedom because essentially, human rights law must serve the purpose of effectively protecting the human dignity of members of any society. Human dignity is therefore a universal human duty, a universal human responsibility. Achieving a life of dignity for all, must involve ensuring a safe, free and happy life for all girls.

Many stakeholders were optimistic that this clear and well-reasoned judgment of the court would be appreciated and give the government and its advisors a better understanding of the need to eliminate harmful and discriminatory provisions that have been discussed. ${ }^{68}$ However, they may be disappointed, because an appeal by the government is pending in the court of appeal, challenging this decision. This portrays the unwillingness of the government to acknowledge and safeguard women's rights and interests at all levels. ${ }^{69}$ The court gave an analysis of the various provisions of international human rights instruments that Tanzania has signed and ratified, which are inconsistent with the disputed provisions. Therefore, it is widely felt that Tanzania has failed to

66 Children's Dignity Forum-FORWARD "Voices of Child Brides and Child Mothers in Tanzania: A PEER Report on Child Marriage" 2014. Children's Dignity Forum-FORWARD http://www.forwarduk.org.uk/wp-content/uploads / 2014/12/Voices-of-Child-Brides-in-Tanzania.pdf (accessed 2019-04-16).

67 Human Rights Watch "Tanzania: Child marriage harms girls" 2014 Human Rights Watcht https://www.hrw.org/news/2014/10/29/tanzania-child-marri age-harms-girls (accessed 2019-04-19).

68 Girlsnotbrides 2018 2: AllAfrica "Tanzania: Child Marriage - a Nasty Bump in the Road for Girls" 2018-06-18. https://allafrica.com/stories/ 201810210053.html: Rueckert "At Least 80 Girls Were Saved from Child Marriage in Tanzania, Government Reports" Global Citizen (2017-12-27) 2: Ministry of Health, Community Development, Gender, Elderly and Children (MHCDGEC) "Child marriage in Tanzania at a Glance" MHCDGEC (2017-03 02) file:///C:/Users/msuyan/Downloads/Child-Marriage-Study.pdf. (accessed 2019-04-19).

69 Girlsnotbrides 20182. 
fully comply with international obligations imposed upon her. ${ }^{70}$ Although Tanzania has passed many new laws with regard to the development of a modern economy, using modern technology and development practices that suit a modern democracy, it seems to be reluctant to accept change in the area of women's rights. ${ }^{71}$ Nevertheless, the decision of the government to lodge an appeal against this decision of the court will serve as an avenue to obtain a precedent judgment from a final court of record.

Other African countries have managed to overcome this harmful and discriminatory culture of early marriage and adhere to international instruments by amending not only their legislation, but also their Constitutions to specifically stipulate the legal age of marriage. These countries include Uganda, whose Constitution affirms that a man and a woman are entitled to marry only if they are each aged 18 and over, and are entitled at that age to equal rights on entering marriage, during the marriage, and at its dissolution. ${ }^{72}$ Similarly, the Namibian Constitution provides as follows:

"[M]en and women of full age, without any limitation due to race, colour, ethnic origin, nationality, religion, creed or social or economic status shall have the right to marry and to found a family. They shall be entitled to equal rights as to marriage, during marriage and at its dissolution."73

Under the Namibia Married Persons Equality Act 1996, which amends the 1961 Marriage Act, the minimum legal age of marriage is 18 years. ${ }^{74}$ Zimbabwe is also among the African countries that stipulates the 18 years legal age of marriage in its Constitution. ${ }^{75}$ Other African countries that used to have discriminatory statutes on the legal age of marriage like Tanzania have already changed their laws. These countries include Algeria, which changed the minimum age of marriage from 18 for women and standardised it to 19 for both men and women in February $2005 .^{76}$ In other countries such as Lesotho, Libya and Rwanda, the minimum age of marriage is over 18 for both girls and boys. ${ }^{77}$ In line with these standards, 32 African countries have set the minimum age of

70 Sueid "Child Marriage in Tanzania: National and International Legal Perspectives" 2017 Zanzibar Year Book 325.

71 Msuya "Harmful cultural and traditional practices: a roadblock in the implementation of the Convention on The Elimination of Discrimination Against Women And the Maputo Protocol on women's rights in Tanzania" (PhD Thesis-UKZN 2017).

72 Article 32 of the Constitution of the Republic of Uganda of 1995, The African Child Policy Forum (ACPF) "Minimum age of marriage in Africa" 2017 ACPF 14. https://www.Girlsnot brides.org/wp-content/uploads/ 2013/ 04/ Minimum-age-of-marriage-in-Africa-March-2013.pdf.

73 Art 14 (1) and (2) of the Constitution of the Republic of Namibia of 1998.

74 The African Child Policy Forum 2017 ACPF 10.

75 The African Child Policy Forum 2017 ACPF 15.

76 Art 7 of the Algeria Family Code of 2005.

77 The African Child Policy Forum 2017 ACPF 7. 
marriage at 18 for both girls and boys. ${ }^{78}$ South Africa, through the South African Law Reform Commission, proposed criminalising both forced and child marriages as a result of, among others, harmful cultural practices. ${ }^{79}$ The section 3(1) of the Recognition of Customary Marriages Act 120 of 1998 (RCMA) of South Africa prescribes the marriageable age to be 18 years for both girls and boys. However, the RCMA, read with the Marriage Act allows persons below the age of 18 to get married provided they have the necessary consent. ${ }^{80}$

\section{Conclusion}

The landmark ruling in this case will remain remarkable on the advancements of women's rights and children's rights as child marriage is not only a catalyst for improving development outcomes, but also a strategic entry point for addressing gender equality. By addressing an issue that affects the long term of women's lives, there is a huge potential to have a catalytic effect on achieving gender inequality worldwide. It is critically important to recognise that early marriages are linked to the continuous violation of girls and women's fundamental rights such as education, health, equality and non-discrimination as well as to live in free from violence and exploitation, including slavery and servitude. As we are zealous waiting for the determination of the appeal of this case, this study maintains that the minimum age for marriage should unequivocally be 18 years of age, for an international legal reason, a domestic legal reason and a social reason. The international legal reason is that Tanzania by increasing the minimum age to 18 for girls would be respecting the international instruments that it has ratified. Several treaty-monitoring bodies of various international human rights have issued statements encouraging governments to increase the age of marriage to 18 for both boys and girls. These bodies include the Committee on Economic, Social and Cultural Rights, ${ }^{81}$ The Committee

78 The African Child Policy Forum "Minimum Age of Marriage in Africa" (2013) Minimum-age-of-marriage-in-Africa-March-2013.pdf: Odala "How important is minimum age of marriage legislation to end child marriage in Africa?" 2013. The African Child Policy Forum 2. https://www.girls notbrides.org/wp-content/ uploads/2013/06/ACPF -Importance-of-min-ageof-marriage-legislation-May-2013.pdf. (accessed 2019-04-19).

79 See The South African Law Reform Commission (SALRC) Revised Discussion Paper 138 Project 138 The Practice of Ukuthwala 2015. http:// www.justice.gov.za/salrc/dpapers/dp132-UkuthwalaRevised.pdf. (accessed 2019-04-19).

80 S 25 and 26 of South Africa Marriage Act No. 25 of 1961: Mwambene "Recent legal responses to child marriage in Southern Africa: The case of Zimbabwe, South Africa and Malawi” 2018. African Human Rights Law Journal 540. http://dx.doi.org/10.17159/1996-2096/2018/v18n2a5.

81 See the Concluding Observations of the Committee on Economic, Social and Cultural Rights, on Mexico (E/C.12/MEX/CO/4); the Concluding Observations of the Committee on the Rights of the Child on Georgia (CRCl C/15/Add.124), South Africa (CRC/C/15/ Add.122) and Costa Rica (CRC/C/ $\mathrm{CRI} / \mathrm{CO} / 4)$. 
on the Elimination of Discrimination against Women, ${ }^{82}$ and the Human Rights Committee. $^{83}$ This statement has been resonating in the researches done by several special rapporteurs and representatives in their research. ${ }^{84}$ Ending child marriage by 2030 one of the targets contained in the new Sustainable Development Goals adopted by world leaders at a United Nations summit in 2015, which Tanzania participated. 85

The domestic law reason of changing the minimum age for marriage to1 8 years is that it will resolve the existing startling contradiction in domestic legislations such as the Law of the Child Act, which define the age of majority as $18 .^{86}$ Also, The Law of Contract Act, which requires one to have attained the age of majority of 18 years in order to contract an agreement and consider any agreement contracted by an individual below this age void. ${ }^{87}$ Marriage is also an agreement, although is considered to be a contract with far reaching obligations than normal commercial contracts, ${ }^{88}$ therefore this would imply that a marriage contract in which one of the parties is a girl below the age of 18 is void. Likewise the Penal Code criminalise and considers having sexual intercourse with a girl aged under 18 with or without her consent rape, unless the woman who is 15 or over is his wife and not separated. ${ }^{89}$ Sections 13(2) and 17(2) which allows a girl to be married while under 14 by leave of the court is contradicting the above section of the Penal Code and at the same time constitute the newly created offence of statutory rape.

The social reasons of amending the legal age of marriage to 18 is that child marriages are prejudicial to the physical, psychological, emotional and economic well-being of half of the country's population, which is

82 Committee on the Elimination of Discrimination against Women, General Recommendation No. 21 (1994) on equality in marriage and family relations, Para 36.

83 Concluding Observations of the Human Rights Council on Uruguay (CCPR/ C/URY/CO/5), Kuwait (CCPR/C/KWT/CO/2), Yemen (CCPR/CO/75/YEM), United Republic of Tanzania (CCPR/C/TZA/CO/4/Add.1), Islamic Republic of Iran $(\mathrm{CCPR} / \mathrm{C} / \mathrm{IRN} / \mathrm{CO} / 3)$.

84 In 2012 the Committees on the Rights of the Child and on the Elimination of Discrimination against Women, together with the Special Representative of the Secretary-general on Violence against Children, the Working Group on the Issue of Discrimination against Women in Law and Practice, together with four other special procedures mandate holders, issued a joint statement calling on States to increase the age of marriage to 18 years for both girls and boys without exception. See United Nations General Assembly, Human Rights Council. Annual report of the United Nations High Commissioner for Human Rights and reports of the Office of the High Commissioner and the Secretary-General, A/HRC/26/22, 2 April 2014, para. 13.

85 Mis "Law alone cannot end child marriage in Tanzania: activist" Reuters (2016-11-03) 2.

86 S 4(1) of Law of the Child Act No 21 of 2009.

87 S 11 (1) and (2) of The Law of Contract Act CAP 345 R.E 2002.

88 Sueid 2017 Zanzibar Year Book 338.

89 S 130(2)(e) of Tanzania Penal Code CAP16 R.E 2002. 
women. ${ }^{90}$ Girls who are allowed to stay with their families and stay in school are able to more fully engage in society, to become financially independent, to care for their families themselves and ultimately to work towards ending poverty. Girls who are married off at a young age are being denied the freedom to make informed decisions later in life. Changing the law alone cannot ultimately end child marriage, they need to be complemented with strategies to change mind-sets of the general community and try to trigger the shift of customs and traditions. As the issue of child marriage is deep-rooted in a male-dominated, patriarchal system where a girl child is not really treated as an equal person. Overall, it is hoped that the Tanzania court of appeal will follow the lead of the Zimbabwean Constitutional Court in Mudzuru's case by rejecting arguments defending child marriages based on custom, culture and belief in clear contravention of human rights commitments. ${ }^{91}$

90 Sueid 2017 Zanzibar Year Book 358.

91 Sloth-Nielsen \& Hove "Mudzuru \& Another $v$ The Minister of Justice, Legal and Parliamentary Affairs \& 2 Others: A review" 2015 African Human Rights Law Journal 567. 